\title{
The Usefulness of Pictorial Aids in Developing Female Iranian Intermediate EFL Learners' Speaking Proficiency
}

\author{
Shahram Afraz ${ }^{1}$, Leila Taghizade ${ }^{1}$, Ali Taghinezhad ${ }^{2 *}$ \\ ${ }^{I}$ Department of English Language, Qeshm Branch, Islamic Azad University, Qeshm, Iran \\ ${ }^{2}$ Research Center for Non-communicable Diseases, Fasa University of Medical Sciences, Fasa, Iran
}

Corresponding author: Ali Taghinezhad, E-mail: taghinezhad1@gmail.com

\begin{tabular}{l} 
ARTICLE INFO \\
\hline Article history \\
Received: April 12, 2017 \\
Accepted: January 21, 2018 \\
Published: January 31, 2018 \\
Volume: 6 Issue: 1 \\
\hline
\end{tabular}

Conflicts of interest: None Funding: None

\begin{abstract}
Speaking is a crucial form of communication in language learning settings. Through speaking skill, ESL/EFL language learners can communicate and convey information. Pictorial aids have been deployed as efficacious mediatory tools in teaching various disciplines such as language teaching. Still, to the best of the researchers' knowledge, a direct look at the impacts of pictorial aids on EFL intermediate learners' speaking proficiency has been less addressed. Thus, the main concern of the present study was to investigate the role of pictorial aids in creating a favorable ground for teaching speaking and how it may affect learners' speaking proficiency. To this end, 40 intermediate EFL learners were selected out of 70 from a private English language institute in Shiraz, Iran. The homogeneity of their proficiency level was established via the administration of Oxford Proficiency Test. Then they were randomly divided into two control and experimental groups. Three instruments were used to answer the research questions: Pre-test and post-test interviews, classroom observation, and a questionnaire. Subsequently, the participants were randomly assigned to an experimental $(\mathrm{n}=20)$ and a control $(\mathrm{n}=20)$ group. During 6 sessions, the experimental group received treatment while using pictorial aids. By contrast, the control group followed their routine instruction at the institution through traditional method, i.e. the tasks of Top notch 2 . Then by the end of the study, an interview was held as a post test in order to monitor any effect the treatment might have on increasing speaking proficiency of the participants under the investigation. The results gained from a post-test were analyzed via t-test indicated that visual aids had a positive impact on the intermediate learners' speaking proficiency in which experimental group outperformed control group.
\end{abstract}

Key words: Pictorial Aids, Young Learners, EFL Speaking Proficiency

\section{INTRODUCTION}

Emphasis on speaking English as a Foreign Language or Second Language (EFL/ESL) is a central goal for language learners and teachers around the world. Richards \& Renandya (2002) pointed out that speaking is an essential element of language ability and provides a good foundation for learners' ability to listen, write and read. Wongsuwana (2006) argues that speaking skills is teachable and has nothing to do with talent. To be able to communicate fluently, having good language skills is considered very important, all of which are listening, speaking, reading and writing. But among these skills, speaking is considered the basis for verbal communication. Oral English is not verbalized in written language, but rather involves learners in mastery of a wide range of sub-skills that together make up the overall language ability (McDonough \& Shaw, 2003). Oral English is an important skill, "accepted by all as a necessary language communication skill" (Burns \& Goh, 2012.p, 15) because it is the high- est skill people use to express their ideas and interact with others. Moreover, speaking is considered the basis of other skills. As Palmer (1965, p. 15) points out, "learning to speak a language is by far the shortest route to learning, reading and writing" (El-Koumy, 2002, p. 86).

There are many benefits to using pictorial teachings in L2 teaching. These benefits are crucial to maintaining the good momentum of student interest in speech. First, the use of visual aids in teaching colloquialisms can make the communication between students and text more compact. Pictorial aids to encourage students to communicate with the interests makes them easier to understand the abstract ideas in the article. This proves that the use of image aids can be used as a "vehicle" that can be used to enrich and enhance speech. Similarly, in the study of language teaching and oral English using multimedia applications, it was pointed out that the insertion of pictorial aids in teaching allowed for a genuine exchange between students. In this way, students can concentrate on speaking. Second, students are motivated 
to speak more. Even if the attitude towards the implementation of the SSP is positive, students are not interested in speaking. Third, the use of picture-assisted teaching can help students to better understand the concept of abstraction. ESL learners learn English learning is very challenging. Learners often have difficulty speaking a second language. In order to cope with this learning problem, you can use the picture aids as a supplementary tool to help students speak. Using photo help can develop their speaking ability. Pictorial aids give students the opportunity to brainstorm ideas and ideas. They can create their own stories without the right or wrong answers. In addition, they can participate in group activities such as paired reading or group activities. They will have the opportunity to create their own story based on their own background experience. In the group work, they can discuss the similarities and differences of each person's interpretation of the photograph.

\section{Significance of the Study}

The importance of this research depends on the needs of the students who are proficient in speaking English through the use of visual aids. Using visual aids can help students understand the underlying meaning of a topic and achieve similarities and differences between each topic. The focus of this study was to investigate the impact of graphic assistance on second language proficiency, which is of great importance to teachers, students, schools and education. This research is also beneficial to other researchers interested in this topic. Specifically, this research will bring huge benefits because it will enhance students' learning process and thus improve their overall academic performance as this will increase students' motivation to learn, increase the clarity of teaching content and make learning more interesting. The results of this study will help to improve teachers' key role in facilitating the use of image aids in teaching and learning. Because it will provide them a basis for understanding the role they play in encouraging and supporting the use of image aids. These findings will further help to shed light on and raise awareness of the importance of using pictorial aids in teaching and learning at school.

\section{Statement of the Problem}

Speaking is a difficult skill to be mastered because "there is a lot more to speaking than the ability to form grammatically correct sentences" (Harmer, 2005, p.iv). That's why students find many difficulties to communicate in the foreign language appropriately. This problem may be due to the limited practice and the lack of exposure to the target language. Therefore, teachers should use different materials and teaching aids in their classes in order to provide more situations and activities for students to strengthen their speaking competence. It is the same for foreign language students it is not impossible to be a good English speaker if you make efforts and follows certain effective strategies to be so. When asked to practice, they are afraid of making mistakes. As the students do not want to participate, so the teacher's control of activities is not good. This reluctance shows their lack of motivation. Unmotivated students do not get any reward in the learning process because they do not give stimuli feedback to their teachers. In fact, in education it is the duty of the teacher to look for strategies that may help students to achieve better and to reach the required level in speaking, for that and as a teacher I thought about a technique to enhance speaking capacities of foreign language learners. I find it crucial to spot the light on the use of pictorial aids as an effective strategy to enhance teaching and learning speaking English in this modest research.

\section{Aim of the Study}

The main concern of the present study was to investigate the role of pictorial aids in creating a favorable ground for teaching speaking and how it may affect learners' speaking proficiency.

\section{Research Questions}

This study attempts to answer the following research questions:

1. What is the role of pictorial aids in developing Iranian intermediate speaking proficiency?

2. How do pictorial aids enhance Iranian EFL learners' speaking proficiency?

\section{Hypothesis}

This study is based on the following hypothesis:

We hypothesize that: if teachers use pictorial aids in their classes, they will be able to enhance their students' speaking proficiency.

\section{LITERATURE REVIEW}

\section{Definitions of Speaking}

English as a foreign language teaching depends on four skills: writing, reading, listening and speaking. The latter is considered the most important communication skill, and most students need to get it. Terminology has been defined by many researchers and authors. Therefore, according to each author's point of view, it has more than one definition. Tarigan (1990, p. 3-4) defines: "Speaking is a language skill developed in children's life that precedes listening skills, at a time when skills are learned." This means that speaking is a basic language skill other than listening. According to Grognet (1997, p.136), "speaking is one of the skills a student must master in learning English. Speaking is an important tool for communication." Moreover, Hornby (1995, p.37) mentions that "speaking is a student The most discernible skill in real life. He adds that "speaking is an important part of everyday interaction and one's first impression is often based on his/her fluent and comprehensive speaking ability." From these definitions, We know that speaking is the most important skill that students should learn to develop in any foreign language.

El-Koumy (2002.p, 85) defines speaking skills from two different perspectives: "From a skill-building perspective, 
speaking is defined as a collection of micro-skills, including vocabulary, grammar, and pronunciation." He added that "speaking from the perspective of language as a whole is defined as the verbal process of meaning construction and expression Tarone (2005, p. 485) states that speaking skills are "the most complex and difficult to grasp." Pawlak, Waniek-Klimczak, \& Majer (2011) point out that speaking is a complex skill as it "synchronizes listening and understanding in real time." Moreover, saying "involves all aspects of communicative competence" Therefore, students should be aware that socio-cultural rules in foreign-language communities are well communicated in every context (p. 4).

\section{The Importance of Speaking Skill}

People express their ideas and interact with each other, providing or asking for information through the phrase "a very important part of everyday life" (Thornbury, 2005, p.1). Regarding the importance of speaking skills, Gammidge (2004, p. 7) states that "speech is a very challenging and important skill for most learners." In addition, Renandya and Richards (2002) pointed out: "A large part of the world's language learners learn English in order to improve their oral ability" (p.201). Many English-speaking students believe that speaking English is a top priority. In addition, they assess their success based on their speaking ability. (Richards, 2008 , p.19) Teaching speaking to many teachers is very important. Burns and Goh (2012, p. 1-2) claim that teachers will do their best to help students develop their speaking skills. There are three main reasons why they are speaking. First, all language learners should be able to communicate with foreign languages. Second, many students have good reading and writing skills, but they have poor listening and speaking skills. Finally, many students remember words in the dictionary, but they cannot speak in English or communicate in formal situations. Therefore, teaching oral English is a very important part.

\section{Audio Visual Aids}

According to Kinder S. James, "audio-visual aids are any design that can be used to make a learning experience more concrete, realistic, and dynamic." Burton said: "Audiovisual teaching aids are organoleptic objects or images that initiate or stimulate and enhance learning." In addition, Good defines "audiovisual aids as an aid to completing learning, assorting and stimulating trigonometric processes ". Therefore, audio-visual aids are very useful devices as they not only facilitate the learning process, but also motivate the students and make the lessons fun.

According to Good's educational dictionary, "audio-visual aids are anything that encourages or conducts learning through hearing or vision". According to Neeraja (2011), "Audiovisual devices are a type of educational device in which information is heard and heard, and in the same context, Mckean and Roberts add that" audio-visual devices are teachers that can be clarified through the use of more than one sensory channel, Establish and link concepts, interpretations and appreciation ".
From these definitions, we conclude that audiovisual teaching aids is an important means of promoting the learning and teaching process. In addition, they help students gain access to foreign languages and develop their speaking skills because they give them the chance to hear and see foreign languages used by native speakers.

Pictorial aids can help foreign language teachers. They can be used in different ways: They inspire classes and bring many kinds of interests to language lessons.

They can help provide context for illuminating the meaning of words used. For example, introducing a conversation between a client and a shop owner in a video helps to provide students with a model of real-life conversation.

They can help teachers improve their understanding of foreign languages and prepare more effective classes because using audio-visual aids can provide students with much thought and gain in a very short period of time.

They can inspire students to speak the language and to read and write.

Listening is a very important skill when learning a language. If we do not have a chance to hear a language, we cannot speak that language fluently. By using audio visual aids, it helps them to listen and learn how to use the language. This not only is interesting, but it also motivates learners.

The context of the literature and the life of foreigners can help provide such information.

In addition, the use of pictorial aid can also help students better retain materials in a very enjoyable learning experience. This is because the more sensory stimulation and participation, the more students learn and retain. Pictorial aids provide many opportunities for listening, speaking and watching a lesson. Students gain more experience and can therefore be motivated to speak, read, or write material. It makes the class more enjoyable and effective.

\section{Relevant Studies}

Some research has been done using audio-visual aids in teaching languages. The use of English-language video in China and the United States is a result of the increasing emphasis on communicative teaching techniques. Video is a rich and valuable resource that Chinese students and teachers love very much. She found that her students liked it because video presentations were fun, stimulating, and challenging to watch. In the same country, Xiaoning (2007) also used video clips in college English teaching. She has found many advantages in language teaching. She said it is both feasible and necessary to use it in the classroom. Andrade, Mercado \& Reynoso (2008) did another study. They found that video as a multimedia technology is a complementary way of providing instructions. The purpose of this study is to explore whether the use of multimedia can help students to learn better. The results show that there is a significant difference in the academic performance of students using multimedia. The conclusion is that multimedia can be effectively used to help students learn data structures, especially binary trees. Students' reaction to visual effects on reading comprehension also shows that the picture enhances the understanding of the text itself. 
Another related study was completed by Allen and Marquez (2011). The purpose of their research paper is to demonstrate how best to use visual aids in ESL/EFL classes. The author details different visual aids, as well as three lesson plans that use a variety of visual aids. The goal is to guide ESL/EFL teachers to make the best use of visual aids in the classroom. Jakubowski's (2013) study begins by emphasizing the importance of vocabulary in second language acquisition. The purpose of this action study is to determine whether to provide illustration teaching to Spanish students through reading and story-telling to help them retain their short-term and long-term vocabulary knowledge. Participants included 67 Spanish secondary students from a rural school district in southeastern Michigan. The data shows that the illustrations are useful for short term terms, but not for long term terms.

In a study by Allou (2013), the introduction of audio-visual aids was considered an effective strategy to improve speaking ability and provided a complete illustration of the proper use of AVA. He submitted a teacher's questionnaire to help us understand the teacher's view of the use of audio-visual aids in teaching languages. At the end of the study, the results we obtained confirm our hypothesis that if we use audio-visual materials, the students' speaking ability will be improved. Finally, this study aims to provide some suggestions and suggestions for teachers and students who can improve their speaking skills.

\section{Method}

A mixed-methods methodology was undertaken in the design of this research in order to triangulate qualitative and quantitative data collection. Teddlie and Tashakkori (2009) maintain that at least one quantitative and one qualitative method is used in the mixed methods study either at the data collection or data analysis of the research, "where neither type of method is inherently linked to a particular inquiry paradigm or philosophy" (p. 323). In that sense, they argue that the mixed methods researchers aim at a workable middle position from multiple viewpoints. Inherent in the use of such methodology is therefore the triangulation of the data derived from the corroboration of quantitative and qualitative findings in one single study (Dörnyei, 2007). Collating data from a range of sources which are collected through a range of research methods can "map out", or explain more fully, the "richness and complexity" of a study (Cohen, Manion, \& Morrison, 2000, p. 112). In recent years, the use of mixed methods has also become increasingly common in studies in the field of second language acquisition and applied linguistics.

\section{Participants}

The participants in this study were 40 female Iranian intermediate learners studying at the English Institute located in Shiraz, Iran. 70 junior high school students went through the Oxford English proficiency test. Those scoring within one standard deviation above and below the mean were selected as a homogeneous group and then randomly assigned to two groups of 20 students, one for the control group and the other for the experimental group. Both classes were held at the institute and were taught by researchers. During 6 sessions, the experimental group received treatment while the control group received traditional instruction at the institution through traditional method, i.e., the tasks of Top notch 2.

\section{INSTRUMENTATION}

\section{Oxford Proficiency Test}

The study was conducted in three phases. In the first phase of the study, researchers tried to select homogenous participants. To do this, participants were administered the Oxford Proficiency Test (OPT). The exam consisted of five reading sections and for each section student had 10 minutes to answer the questions. Reading sections included reading comprehension, vocabulary, communication and grammar. The mean was around 45 and the standard deviation was 16 . The reliability of the test was calculated by Shamsi and Rahimy (2017) through Cronbach's Alpha formula $(r=0.71)$.

\section{Textbook}

The textbook used in the present study was the Top Notch series (Ascher \& Saslow, 2011), a six-level communicative English course with two beginning entry levels namely fundamentals A and fundamentals B for adults and young adults. Generally, the Top Notch series consist of 12 textbooks on the whole, written by Joan Saslow and Allen Ascher in 2006 and published in the United States of America by Pearson Longman Incorporation.

\section{Pre-test}

A pre-test of IELTS speaking tasks was given to test participant's speaking ability. The test is a registered trademark of Cambridge University ESOL (2012) including personal questions about learners, their families, their work, their education and other familiar topics. The tasks were used as pre-tests to assess learners in the experimental group before treatment. Since the IELTS speaking topics mentioned above all contained a lot of questions, some of them were used for pre-test and some of them were used for post-test in experimental and control groups to assess the proficiency of the learner for their effect on speaking. Researchers then used evaluation criteria for speaking assignments. The participants' marks ranged between 0 and 20 in the control and experimental groups. The oral production of participants was recorded verbally recorded and two raters scored the resulting audio file. The raters used IELTS speaking rubrics (public version) to assess learners' speaking skills. Finally, participants were divided into experimental and control groups; each group consisted of 20 participants. The correlation coefficient between the two sets of scores given by the two raters was $r=.72$.

\section{Post-test}

After 6 weeks of treatment in the experimental group, oral tests were conducted on the participants in order to check 
the treatment effect. In the final week of the experiment, post-test experiments were given to the control and experimental groups. The learners' oral productions were recorded, and the resulting audio file was rated by two scoring staff based on IELTS speaking criteria (public version). In this step, both raters used the same standard (IELTS Speaking Rubrics) to rate learners' speaking skills. In order to address the first research question, we studied the improvement of learner's speech. The correlation coefficient between the two sets of scores given by the two raters was $r=.76$.

\section{Classroom Observation}

In order not to miss the observational features, the researcher made an observation schedule. To supplement the observation, digital devices (cell phones) were used to record what happened. According to Denscombe (2010), the use of systematic observations has some drawbacks due to the simplicity of the observation plan. Categorizing obvious behavior rather than intentions becomes the focus of the research, so using non-holistic methods may ignore the background information. Despite this shortcoming, researchers have found observations that are more suitable for this study because of the following advantages. First, systematic observation is advantageous because it allows for direct data collection and direct recording of what observers do, which may be different from what they say. Second, the use of an observation schedule reduces the risk of selective perception and produces objective observations as it effectively eliminates any bias in the observer's current emotion or personal background. Third, it also effectively provides the means to collect large amounts of data in a relatively short period of time. To compensate for the weakness of the observation method, I decided to supplement the observation with the questionnaire.

\section{Questionnaire}

The questionnaire was composed of 10 questions, three of which were close-ended and the rest was open-ended. It aimed to elicit personal opinions of the students (Appendix 1).

\section{Procedure}

The participants of this study were secondary female students studying at a private language institute in Shiraz, Iran. The purpose of this study was to test the impact of pictorial aids on EFL learners' oral proficiency while exploring their attitudes toward speaking. The Oxford Proficiency Test was given to the participants in both groups and it was ensured that the two groups were homogeneous and were all at an intermediate level. Forty of the 70 participants were enrolled in this study, aged 16-20 years. Subsequently, participants were randomly assigned to the experimental group $(n=20)$ and the control group $(n=20)$. The participants in the experimental group were given 6 sessions instruction (once a week) for 90 minutes each. Participants in the control group were instructed oral communication in the traditional way, and the experimental group was given a clear picture-assisted teaching. Students in the experimental and control groups practiced speaking tasks, such as conversations, discussions, stories and role plays, in pairs or groups. Classroom activities were selected from the Top Notch 2 speaking and communication sections of the course book. Each session had three main parts: pre-activity, main activity, and post-activity. During the previous activity, the teacher started the class by saying hello to the students. Here, the teacher made some warm-up questions to guide students' major activities. The goal was to help students relate their previous and new knowledge. During the main event, students were asked to see the sequence of pictures and were asked to answer some questions to check their understanding. Then the class brainstormed and collected all the information about the picture. After brainstorming, they made some predictions based on the pictures. Here, teachers and students discussed more pictures. During this process, the teacher also explained some of the expected skills. After the activity, students were asked to work in pairs and in groups. Then, there was a group/class discussion on the rationale for applying image aids. In addition, participants were asked to determine the impact of selected graphical aids on the learning process. Students were then asked to supplement the pictorial aids in everyday oral class, especially dialogues, discussions and role plays.

\section{Data Collection}

The present study benefited from quantitative and qualitative data collection methodology. As to the quantitative part, Oxford Proficiency was administered to homogenize the participants. However, the qualitative part of the study was a pretest to check the learners' knowledge of speaking before the intervention. After 6 intervention sessions of using pictorial aids to which the experimental underwent, all the participants took the post-test to investigate their achievement regarding their L2 speaking proficiency. Meanwhile, classroom observation was used during each session in order to investigate learners' progress in speaking and their attitudes toward pictorial aids technique as well. It is noteworthy that the control group received no treatment and they were taught traditionally without using any pictorial aids.

\section{DATA ANALYSIS AND FINDINGS}

\section{Oxford Proficiency Test}

The research question of this study dealt with investigating the effect of pictorial aids on speaking skill of Iranian intermediate EFL learners. At the beginning of the study, all subjects took Oxford Proficiency Test to ensure they were intermediate EFL learners. The estimated language proficiency mean of control group amounted to 45.35, and for experimental group 44.90. It can be inferred that both group have almost the same proficiency level. Descriptive statistics is presented in table 1 :

\section{Pre-test/Post-test}

In the next stage, all subjects were administered a speaking test as a pre-test. It was used to ensure that there was no sta- 
tistically significant difference between the experimental and control groups at the start of the study. Table 2 shows that the mean and standard deviation of oral skills of subjects in the experimental group were 14.95 and 1.57 , respectively. The mean and standard deviation of the subjects in the control group were 14.08 and 1.47, respectively. Independent sample t-test was performed to measure the difference of the mean scores of the pre-test. The reported P value was 0.931 , greater than 0.05 (Table 2). Therefore, there was no significant difference between the experimental group and the control group in speaking ability. In other words, the experimental and control groups were homogeneous and comparable at the start of the study.

A speaking test as post-test was administered to all subjects in experimental and control groups at the end of the treatment in order to measure their overall speaking achievement. To show the amount of enhancement of the experimental group, the performance of the subjects of this group at pre-test and post-test was compared. The comparison of the pre- and post-tests of the experimental group revealed a remarkable achievement in the speaking ability mean scores of the students. According to the pre-test and post-test mean values of 14.95 and 18.30 as well as a significant level of $p=$ (.000), $\mathrm{p}<.001$ (table 3 ), the experimental group has shown a great difference at the end of the experiment.

On the other hand, to indicate the amount of progress of the control group, the performance of subjects in the pre-test and post-test was compared. The comparison of the pre- and post-tests of the control group illustrated achievement in speaking ability mean scores (Table 4) of the participants. The pre-test and post-test mean values of 14.08 and 15.00 show development in the participants' speaking ability and the level $p=0.000$, $(p<0.001)$ obtained through paired samples t-test indicates a statistical difference in speaking ability of the control group (Table 4). It is clear that the control group's development compared to that of experimental group is very slight.

Finally, an independent sample test was run to analyze all subjects' scores in the post-test. The estimated mean and standard deviation of the subjects' speaking skill in the experimental group amounted to 18.30 and.66 respectively and the estimated mean and standard deviation of subjects speaking skill in the control group amounted to 15.05 and.34(Table 5). An inspection of the mean scores showed that there was a considerable difference between the experimental and control groups in terms of overall speaking ability development. Moreover, the independent-samples t-test showed that this difference was statistically significant $(\mathrm{p}=0.000), \mathrm{p}<0.05$. Therefore, the null hypothesis is accepted and the positive influence of pictorial aids on the subjects' speaking skill was confirmed (Table 5).

The obtained results of this study correlated with the existing studies in the literature which portrayed that imple-

Table 1. Descriptive statistics for the oxford proficiency test (OPT)

\begin{tabular}{lcccccc}
\hline & N & Minimum & Maximum & Mean & Standard deviation & Variance \\
\hline Control group & 20 & 21 & 76 & 45.35 & 16.519 & 272.884 \\
Experimental group & 20 & 19 & 78 & 44.90 & 16.767 & 281.144 \\
\hline
\end{tabular}

Table 2. Results of speaking pre-test for the experimental and control groups

\begin{tabular}{lccccccr}
\hline Groups & No & Mean & SD & Standard error & t & df & Sig.(two-tailed) \\
\hline Experimental & 20 & 14.95 & 1.57 & 3.88 & & & \\
Control & 20 & 14.08 & 1.47 & 3.41 & 0.872 & 38 & 0.931 \\
\hline
\end{tabular}

Table 3. Comparison of the speaking pre-test and post-test mean scores (experimental group)

\begin{tabular}{lccccccc}
\hline Experimental & No. of students & Mean & SD & Standard error & t & df & Sig.(two-tailed) \\
\hline Pre-test & 20 & 14.95 & 1.57 & 0.40 & & & \\
Post-test & 20 & 18.30 & 0.66 & 0.15 & 12.27 & 19 & 0.000 \\
\hline
\end{tabular}

Table 4. Comparison of the speaking pre-test and post-test mean scores (control group)

\begin{tabular}{lccccccc}
\hline Control & No. of students & Mean & SD & Standard error & t & df & Sig.(two-tailed) \\
\hline Pre-test & 20 & 14.95 & 1.57 & 0.35 & & & \\
Post-test & 20 & 15.05 & 1.52 & 0.34 & 0.44 & 19 & 0.000 \\
\hline
\end{tabular}

Table 5. Comparison of experimental and control groups' post-test results

\begin{tabular}{lccccccc}
\hline Groups & No. of students & Mean & SD & Standard error & t & df & Sig.(two-tailed) \\
\hline Experimental & 20 & 18.30 & 0.66 & 16 & 12.27 & 19 & 0.000 \\
Control & 20 & 15.05 & 1.54 & 0.34 & 0.43 .7 & & \\
\hline
\end{tabular}


menting visual aids in classroom instruction could improve learners`speaking skill. Therefore, it is in common with the results of all studies indicating the usefulness of students participation in learning process of speaking skill. Due to the nature of this technique students are completely participated in classroom activities and indirectly or directly learn speaking skill. The researchers, who support the effectiveness of pictorial aids technique, argued that this technique is better than the usual ways of teaching speaking. The reason is that pictorial aids technique requires students to engage in guided learning and problem solving and as a result improves their speaking skill. Those researchers, who advocate the use of pictorial aids in recommend that it is influential for language learners since it enable students to talk about different topics on their own words and make use of their previous when face some difficulties. The results showed that the experimental group improved their speaking ability in the oral test (post-test), indicating that the pictorial aids played an important role in improving the learners' learning process of English and their cognition of oral skills. The results of this study showed that the experimental group performed better than the control group in the post-test.

A questionnaire was designed to obtain information about using pictorial aids in EFL classrooms. Students are told that their response will only be used for research purposes. These ten questions were related to the use of pictorial aids in English classrooms, the relevance of English classes, and the relevance of English textbooks. Most questions were open-ended, and students were asked to be fair about their point of view. It consisted of three closed questions and seven open questions. Some people think that open-ended questions can provide more insights by activating student thinking processes. Students are encouraged to seek the help of researchers as they discover an unintelligible problem. Most students' answers to these 10 questions were related to the changes they observed in the classroom observation. Respondents appreciated the introduction of pictorial aids as they found them interesting and rewarding. Students also noticed changes in the visual effects they had used. The feeling they reported was even more positive, thanks to the choice of theme for the pictorial aids. An analysis of student responses to closed-ended questions is shown in the Table 6 below.

1-Did you like the lesson plans 3- Do you find the need for the English 5.Are pictorial aids used in your

carried out during these six weeks? teachers to use pictorial aids in the class classroom frequently and effectively?
Table 5 shows that most of the students like the technique used in the class during these three weeks of intervention. However, 25\% did not like the technique. They were in favor of traditional methods of teaching. One student noted that "mechanical drills are easier to be performed, and implementing the technique is just waste of time”. With regard to next question it can be concluded that again most of the students (nearly 80\%) find the need for English teachers to use pictorial aids in the class. However, 20\% did not find the need for the English teachers to utilize pictorial aids in the class. This shows that there are students who believe that the pictorial aids teaching sessions are not very important in the English language classroom. Students gave interesting answers to this question. A student stated that "some students cannot get the information in traditional ways but using pictorial aids will help them to understand better." As a matter of fact, the technique activates higher levels of thinking. Students also felt that pictorial aids can be beneficial when teachers find some language terms difficult to explain on the white boards. EFL students believe that pictorial aids can enhance their understanding. Few students believe that teachers need not use pictorial aids in the class. One opinion was "that's because some teachers can use other techniques other than pictorial aids which make lessons understandable". These students seem to be comfortable with traditional methods of teaching as well.

Response of the students to the last close- ended question indicates that most of them find that pictorial aids are not used frequently and effectively in the classroom (Figure 1). Just $35 \%$ of the students point out that English teachers use pictorial aids in the EFL classroom. There seems that most of the teachers do follow rules dictated to them in English courses and they don't have any creativity and independency in choosing their own teaching methodology. It was observed that just a few teachers do use pictorial aids while much of them do not use pictorial aids in the classroom.

An analysis of data indicates that only $25 \%$ of students responded to the sixth question (If yes, how are they related to your lesson?). Students who responded were not clear as to how these pictorial aids are related to their lessons. A student observed "Most of our English classes are teacher-centered, and we have passive role most of the time." It is observed that few English teachers use pictorial aids for making classroom sessions active. Use of pictorial aids in the classroom enhances students' receptive skills.

Data analysis indicates that only $15 \%$ of students responded to the question (If no, why they are not used?). However,

Table 6. Analysis of student responses to closed-ended questions

\begin{tabular}{|c|c|c|c|}
\hline Question & Response & Score & Percent \\
\hline 1-Did you like the & Yes & 15 & 75 \\
\hline lesson plans carried out during these six weeks? & No & 5 & 25 \\
\hline 3- Do you find the need for & Yes & 16 & 80 \\
\hline the English teachers to use pictorial aids in the classroom? & No & 4 & 20 \\
\hline 5- Are pictorial aids used in & Yes & 7 & 35 \\
\hline your English language classroom? & No & 13 & 65 \\
\hline
\end{tabular}


Table 7. Provides an explanation for the criteria and shows how items were categorized

\begin{tabular}{lccc}
\hline Session & Number of low level & Number of medium level & Number of high level \\
\hline First & 15 & 2 & 3 \\
Second & 12 & 4 & 4 \\
Third & 10 & 7 & 3 \\
Forth & 9 & 6 & 5 \\
Fifth & 6 & 7 & 7 \\
Sixth & 3 & 4 & 13 \\
\hline
\end{tabular}

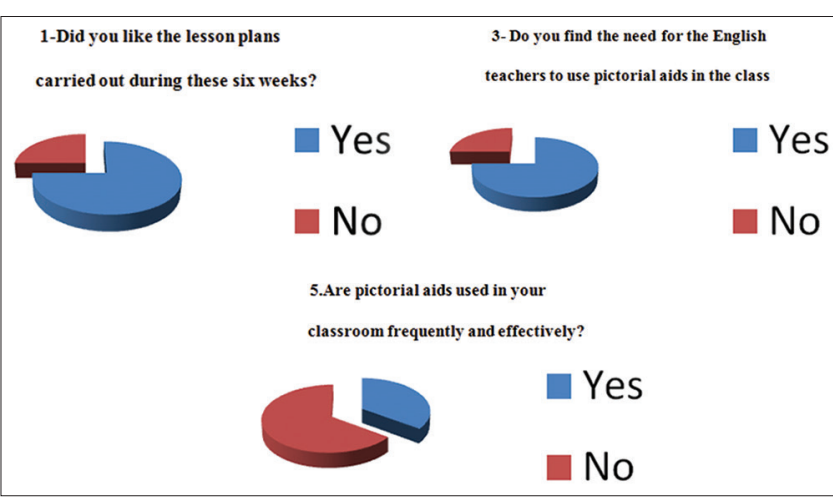

Figure 1. The percentage of students' responses

student pointed out "the teacher does not have enough time to use the technique in class". Another student said that "because some teachers are not experienced enough to find the technique important."

Regarding students' response to the eighth question it can be concluded that most of them find pictorial aids useful. However, $25 \%$ of students find the technique useless. Because most of the course books which are used to teach speaking such as New Interchange and Touchstone have few pictures related to the content, and the teachers do not search for more suitable pictures on the web, so these students probably find the technique difficult to comprehend.

With regard to ninth question, data analysis showed that only $30 \%$ of students responded it. (If yes, how are they useful?). However, students pointed out that pictorial aids will help in improving comprehension and conversational skills. Another student noted that "pictorial aids make the vocabulary and sentence retention easier and for a long duration." Students felt that information can be retained for longer duration.

With regard to the last question (What are your last recommendations?), a student noted "There should be more pictures in the books because pictures offer comfort, they are fun and non-threatening. They encourage joy in reading, speaking, listening, and writing". EFL students are of the opinion that English teachers should have the requisite technical knowledge to choose the most suitable pictorial aid during classroom sessions. Another student noted "it is very good because the technique makes the content of the lesson more tangible".

The questionnaire was used as a research tool to obtain information about students' perceptions of pictorial aids and resources, providing information on important issues in the classroom teaching process. In informal interactions with students, it was pointed out that such questionnaires helped them to reflect on aids and resources for pictures. Students' English language proficiency was taken into account in the design of the questionnaire. Classroom observation was based on using the checklist (Appendix 2) and field notes on student behavior and attitude to activities. In order to assess the overall participation and participation of students during their activities and strategies, each project was marked ' $L$ ' as low participation, ' $\mathrm{M}$ ' as medium participation, and ' $\mathrm{H}$ ' as high participation.

The first session started with a brainstorming session and students were asked to talk about their favorites, entertainment, movies, and more. Brainstorming was monopolized by 3 or 4 students who were usually active. To raise the class's participation for the next exercise, I started asking them separately. It should be noted that the level of participation was quite low. After the introduction of technology, the classroom environment changed. The number of students participating in the "movie and entertainment" discussion increased significantly. After watching and watching activities, students showed more interest and participation. Most students were focused on the discussion, they were willing to participate. One fact that should be emphasized is that some of them were passive or shy students but in the first session, they had clearly changed their attitude toward active participation. As the project titled "Make Your Own Experiences with the movies" explains, students asked a few questions to clarify what they were doing. As soon as you start working, your attitude becomes more relaxed and clear. They asked questions, laughed at funny examples, and more. When students were asked to form a team, the entire class was immediately divided into four groups. The level of participation at this session can be assessed as almost high. Most students shared their experiences and thoughts and made short sentences like "My favorite entertainment is." or "My favorite movie is." Students were confident in expressing their thoughts.

At the second meeting, after a brainstorming session, students had to make a conversation based on the picture at hand and the subject of the lesson (staying at the hotel), which would be used later for role-playing activities. They tried to complete the conversation and were prepared to perform in class. It should be noted that although the topics introduced were new to the students, they quickly understood and performed most of the activities well. Almost every student took part in the event, and they seemed to have almost a high-level engagement as they kept talking about the photos after the exercise.

The third session centered around "picture dictation" techniques. This is a normal dictation change. You do not 
read a passage, but describe a picture that a student cannot see. They draw what you say and compare their version with the original version after checking with their partner. For example, this lesson on prepositions is very effective. Say, "Draw a table in the middle of the room, a cat below the table." to see what everyone came up with. It can also be paired with a student description and another picture, and then the two characters switch and keep playing. Moderate participation.

In the fourth meeting, each pair should determine the similarities and differences between two different images (two types of drivers). After sharing with peers and classes, students could generate sentences and paragraphs about images. For beginners, the teacher could provide the following sentence frame:

"Both pictures have $\cdot$

- "One difference is
second picture there is

Fifth session was designed around the "Spot the Difference" technique. This is the well-known game using two pictures with a number of differences between them. In this version, the students work with a partner. Each student has a picture, but they don't show their partner the pictures. They have to find the differences by talking to each other, describing their pictures and discovering what doesn't quite match up. I elaborated the technique in details, and some related pictures were given to each pair in order to practice the technique. Lastly, each pair was asked to perform it for the rest of the class. Level of participation and motivation was almost high.

In the sixth session, sets of sequencing pictures were distributed between subgroups by which they were supposed to tell a story from beginning to end. The procedure is as follows:

Each member of the group in turn describes their picture without showing it. Once everyone has described their picture, they try and guess the correct order of the story and put the pictures face down in that order. Then they'll turn them over and see if they're right. They can then retell the story. The technique was rather enjoyable for them, and the level of participation was almost higher than the previous session.

In each session the students were helped with the correct pronunciation and meaning of difficult words.

\section{DISCUSSION}

The study aimed to understand the extent to which pictorial aids were used to influence the speaking ability of EFL students in Iran. It seems that Iranian students tend to be more motivated rather than interactive. This study started from the assumption that image-based teaching tools improve the oral ability of middle-level language learners. They promote student motivation which makes them more interested and involved in the classroom. The results showed that the use of pictorial aids affected the oral ability of intermediate and English learners. Pictorial aids can promote students' motivation to learn, which makes them more interested in class participation, but only habitually reading texts, especially authentic texts such as documentaries, choosing to passively sit in their seats. Seemingly, to stimulate these students to participate in classroom activities is not easy, because some students do not have this information, and they are not interested. And, if not all, many students enjoy photos at least for entertainment. The results of this study are consistent with Idris's work (2015). He found that audio-visual materials play an important role in learners' oral skills teaching.

The study was conducted at a private language institute in Shiraz, Iran. As a result, current research can be replicated in other regions and the door to future research also welcomes the same research performance at university or high school. This experiment is for oral skills with intermediate students. The same study can be repeated at other language levels (primary, intermediate and above) for more generalized results. In this study, only one audiovisual aid (i.e. picture) was used, but researchers could use categories (e.g. video, audio, etc.) to improve learners' speaking skills (Table 7). Finally, an important clue about more research on the educational uses of pictorial aids may be teachers' attitudes toward the use of these aids and the reasons for using them from their point of view.

The use of pictorial aids with innovative teaching practices can make the presentation more effective and enjoyable. To make practice skills effective, teachers need to experiment and test resources before classroom. Knowledge of pictorial aids can make EFL classes interactive. When new topics are introduced in the classroom, these resources are more suitable for use. When teachers cannot effectively use these resources, students often find them irrelevant. The individual teacher's self-awareness and the ability to use teaching aids have a direct impact on the classroom environment. Moeller and Reitzes (2011) argue that teachers need to be proactive in order to use teaching aids effectively in the classroom. Students benefit from a witty and interesting learner-centered EFL class. In the classroom, students observe the teacher's attitude, teaching style and innovative skills. Students form ideas and assumptions every day, and a successful teacher must carefully combine the course content with the graphic aids to effectively teach in the classroom. Honey and Moeller (1990) point out that an important factor that affects teachers' use of pictorial aids in the classroom is their teaching beliefs about learning and teaching. A practicing teacher should recognize that using too much picture material at one time can cause boring things. Students may see frustration and negative tendencies when technology does not meet their cognitive level. The use of these resources requires more attention as it provides the opportunity for effective communication between teachers and students in the EFL classroom. Foreign language teachers should have a deeper understanding of the selection and use of these resources. Teachers have a responsibility to check the quality and authenticity of these resources. On the positive side, the effective use of these assistive tools saves learning time and allows students to develop keen observation and interest in the classroom. Given that each teaching and learning situation is different, teachers need to understand the strengths and the combination of aid for each type of assistance. 


\section{CONCLUSION}

The main purpose of this study was to maximize students' speaking skill via pictorial aids technique. This research may be helpful to English language teachers who have some sorts of difficulty in teaching speaking skill to EFL/ESL learners. The study motivates teachers to work on speaking skill through the utilization of pictorial aids. The other advantage of the outcomes of this research for teachers is that it may give language teachers the insight that incorporating aforementioned technique into language teaching process could be beneficial. It also can determine a new way for English teachers to direct their learners moving towards meaningful learning. This study examined students' performances in improving their speaking skill. In other studies also males could be involved and the differences between males and females' performances and attitudes could be investigated.

The results of this study contribute to the language teaching process in the educational environment. First, for foreign language learners, because they are involved in the learning process, it paves the way for them to understand the article more deeply. This led to the successful cooperation of the way of communication as a common achievement and approval of the outcome. Instead of being reticent in class, several learners participated in the speech at the same time. In addition, encouraging learners to use this cognitive strategy, especially using photo help and other types of speaking skills, has been successful for both teachers and learners.

In addition, the use of graphical aids in the classroom will help teachers reduce their role as classroom teachers in the classroom, prevent students from acting as listeners or counterparts in the classroom, and will make learners interact more often than before. Language researchers interested in doing research in the area of language learning and teaching are another group that can benefit from the research in this paper. They can provide new ideas for more and newer research on teaching tools (such as pictorial aids) and their impact on language teaching in different contexts.

Since this research was conducted in a previously specially designed environment (this is a classroom and participates in two groups of same learners who are taught how to use pictorial aids in class), one of the limitations of this study is that the result may not be replicable to other Iranian educational curricula; however, this limitation will be overcome if teachers in the current education department are to be familiar with the use of pictorial aids in the classroom and to provide the necessary facilities for classroom use of pictorial aids. Another limitation of this study is that all learner participants in this study are intermediate learners, and the level and age of participants may limit the universality of the findings; as an example, we cannot assign this The results of the study are generalized to elementary, intermediate, advanced intermediate or advanced learners unless similar studies are conducted with the learner participants being beginner, intermediate, intermediate or advanced learners.

\section{REFERENCES}

Allen, K., \& Marquez, A. (2011). Teaching vocabulary with visual aids. Journal of Kao Ying Industrial \& Commercial Vocational High School, 1(9), 1-5.
Allou, A. (2013). The effect of audiovisual aids in teaching speaking skill among EFL learners a case study: Second year students of English at Biskra University. Biskra: People's Democratic Republic of Algeria Ministry of Higher Education and Scientific Research Mohammed Kheider University of Biskra Faculty of Letters and Languages English Division.

Andrade, E. L. M., Mercado, C. A. A., \& Reynoso, J. M. G. (2008). Learning data structures using multimedia-interactive systems. Communications of the IIMA, 8(3), 25-32

Ascher, A., \& Saslow, J. (2011). Top notch series. Longman: Pearson Education.

Burns, A. \& Goh, C. M. (2012). Teaching speaking. Cambridge: Cambridge University Press.

Cohen, A. D. (1990). Language learning: Insights for learners, teachers, and researchers. New York: Prentice Hall.

Cohen, L., Manion, L., \& Morrison, K. (2000). Naturalistic and ethnographic research. Research methods in education, 5, 137-157.

Denscombe, M. (2010). The good research guide: For smallscale social research projects (Open UP Study Skills). Berkshire: McGraw-Hill.

Dornyei, Z. (2007). Research methods in applied linguistics. Oxford University Press: Oxford.

El-Koumy, A. (2002). Teaching and learning English as a foreign language: A comprehensive approach. Dar annashr for universities: Cairo, Egypt.

Gammidge, M. (2004). Speaking extra. Cambridge: Cambridge University press.

Ginther, A. (2002). Context and content visuals and performance on listening comprehension stimuli. Language Testing, 19(2), 133-167.

Grognet, A. G. (1997). Definition of speaking skill. Providence: Jamestown publisher.

Harmer, J. (2005). The practice of English language teaching. London: Pearson Education Ltd.

Honey, M., \& Moeller, B. (1990). Teachers'beliefs and technology integration: Different values, different understandings. (ERIC Document Reproduction Service No. ED326203)

Idris, A. O. (2015). The effect of Audio-visual materials in teaching and learning of speaking of skills in junior secondary schools in Katsina State Nigeria. International journal of social science and humanities research 3 (3), 50-58.

Jakubowski, A. (2013). Using visual aids in the secondary language classroom: an action research study on the use of illustrations during TPRS instruction. The University of Toledo Publications: Toledo

Koumy, E., \& Salam, A. (2002). Teaching and learning English as a foreign language: A comprehensive approach. Dar An-Nashr for Universities, Cairo, Egypt.

McDonough, J., \& Shaw, C. (2003). Materials and methods in ELT. Oxford: Blackwell.

Moeller, B., \& Reitzes, T. (2011). Integrating Technology with Student-Centered Learning. A Report to the Nellie Mae Education Foundation. Education Development Center, Inc. 
Neeraja, K. P. (2011). Textbook of communication and education technology for nurses. JP Medical Ltd.

Oxford Learner's pocket dictionary. (2009). Oxford: Oxford University Press.

Palmer, H.E. (1965). The principles of language study. London: Harrap.

Pawlak, M., Waniek-Klimczak, E., \& Majer, J. (Eds.). (2011). Speaking and instructed foreign language acquisition. Multilingual Matters.

Richards, J. C. (2008). Teaching listening and speaking: From theory to practice. Cambridge: Cambridge University press.

Richards, J. C., \& Renandya, W. A. (Eds.). (2002). Methodology in language teaching: An anthology of current practice. Cambridge: Cambridge university press.
Shamsi, M., \& Rahimy, R. (2017). The Impact of L2 semantic tasks (L2 collocation versus L2 definition) on Iranian intermediate EFL learners' vocabulary achievement. International Journal of Research in English Education, 2(1), 58-67.

Tarone, E. (2005). Speaking in a second language: Handbook of research in second language teaching and learning. Hillsdale, NJ: Lawrence Erlbaum Associates.

Tarigan, G. (1990). Berbicara sebagai suatu ketrampilanBerbahasa. Bandung: Angkasa.

Thornbury, S. (2005). How to teach speaking. Pearson: Longman Wongsuwana, T. (2006). Speech could be trained. Thailand Education Journal, 21, 44-50.

Xiaoning, W. (2007). On the use of video clips in college English teaching. Canadian Social Science, 3(2), 84-96. 
Appendix 1. Questionnaire for students

This questionnaire is a tool to investigate the significant role of pictorial aids in the teaching process and their contribution to the success of intermediate students in the speaking skill at a language institute in Marvdasht, Fars, Iran. Your contribution is vital to achieve the objective of this study, we will be very grateful if you take this work seriously.

1. Did you like lesson plan carried out during these six sessions? Yes/No

2. Do you find the need for the English teachers to use pictorial aids in the classroom? Yes/No

3. If yes, why do they need to use pictorial aids in the classroom?

4. If no, why do you think they should not use pictorial aids in the classroom?

5. Are pictorial aids used in the English Language classroom? Yes/no

6 . If yes, how are they related to your lesson?

7. If no, why are they not used?

8. Do you find the pictorial aids useful?

9. If yes, how are they useful?

10. Your suggestions about pictorial aids in the English language classroom.

Appendix 2. Classroom Observation Checklist

Observer's Name:................... Date:....

Class Observed:.................... Time:.....................

\begin{tabular}{|c|c|c|c|c|c|c|c|c|c|c|c|c|c|c|c|c|c|c|}
\hline \multirow[t]{2}{*}{ Student's name } & \multicolumn{3}{|c|}{ First session } & \multicolumn{3}{|c|}{$\begin{array}{l}\text { Second } \\
\text { session }\end{array}$} & \multicolumn{3}{|c|}{$\begin{array}{l}\text { Third } \\
\text { session }\end{array}$} & \multicolumn{3}{|c|}{$\begin{array}{l}\text { Fourth } \\
\text { Session }\end{array}$} & \multicolumn{3}{|c|}{ Fifth session } & \multicolumn{3}{|c|}{ Sixth session } \\
\hline & $\mathbf{L}$ & M & H & $\mathbf{L}$ & $\mathbf{M}$ & $\mathbf{H}$ & $\mathbf{L}$ & M & $\mathbf{H}$ & $\mathbf{L}$ & M & $\mathbf{H}$ & $\mathbf{L}$ & M & $\mathbf{H}$ & $\mathbf{L}$ & M & $\mathbf{H}$ \\
\hline
\end{tabular}

